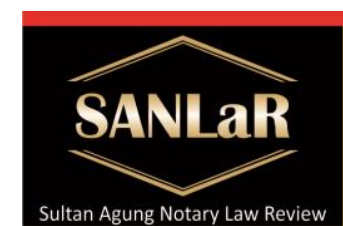

Volume 2 Issue 3, September 2020
Sultan Aqung

Notary Law Review

Notary Role in Implementing the Credit...(Dian Oktavian Anggraeni)

ISSN 2686-4428

published by Faculty of Law Sultan Agung Semarang

\title{
Notary Role in Implementing the Credit Agreement and Process of Binding Liability
}

\author{
Dian Oktavian Anggraeni ${ }^{*}$ and Sukarmi ${ }^{* *}$
}

*) Students of Master of Notary Law, Universitas Islam Sultan Agung (UNISSULA) Semarang, E-mail: dianoktavian@gmail.com

${ }^{* *}$ Lecturer of Master of Notary Law, Universitas Islam Sultan Agung (UNISSULA) Semarang

\begin{abstract}
The objectives of this research are: 1) To determine the role of the Notary in implementing the credit agreement and binding Mortgage Rights, 2) To find out the obstacles faced by the Notary in implementing the credit agreement and binding the Mortgage, 3) To find out the solutions provided by the Notary in implementing the credit agreement and binding Mortgage Rights. The data used in this study are primary and secondary data collection, which can support the assessment, which is then analyzed using a sociological approach. Based on the research results concluded that: 1) The role of the Notary in the implementation and process of binding Mortgage Rights lies in his responsibility. Namely the responsibility for the credit agreement deed made by him and the legal protection of the parties involved in the deed if there is a dispute between the parties in the future, then that becomes a reference for the authorized legal official., 2) Constraints faced by the Notary such as the inability of the parties, the difficulty of the parties in completing the terms of the credit agreement and bonding of Mortgage Rights, the registration process of Mortgage Rights at BPN which is too long, 3) The solution provided by the Notary is to reschedule the implementation of the credit agreement or authorize another party if unable to attend, complete the requirements credit agreement and bonding of Mortgage Rights by asking for help from a Notary partner, charging fees to the Customer to speed up the registration process at BPN.
\end{abstract}

Keywords: Credit; Agreement; Liability.

\section{Introduction}

Banks continue to compete in channeling funds or what is often referred to as credit, competition is getting tougher among banks throughout Indonesia. Each bank must be able to determine the right alternative to attract customers' interest and trust to save their money in the bank and convince the public that the credit channeled can increase the business growth of prospective debtors, besides that it can also increase economic development in Indonesia.

Credit facilities to be provided to debtors must go through several steps, one of which is entering into a credit agreement. Bank credit agreements are generally made in writing and in the form of a standard agreement, this agreement must be made in the 
form of an authentic deed. Therefore, it is certain that it will involve a third party, namely a Notary, to ensure the operation of the credit agreement between the Debtor and the Bank, so that a legal relationship will emerge between the two. According to Article 1 of Act No. 2 of 2014 concerning the position of Notary Public. Notary is a public official who has the authority to make authentic deeds and other powers as in this Law.

The credit agreement has a very important function in the Bank to provide credit to debtors, in which there are ways of granting, managing and managing credit that have been agreed by both parties. The implementation of the credit agreement made by the Notary does not go as expected so the Notary must be careful in implementing it. The notary must be objective between the Debtor and the Bank in implementing the credit agreement, so it will not cause losses between the two parties.

Notaries play a role in providing legal protection, legal certainty and justice for them, one of which is legal protection for banks regarding guarantees tied to a mortgage used to provide credit facilities and will be contained in the credit agreement of both parties, and used as collateral for repayment of debts for the Bank, if the Debtor is in default.

Notaries are given the authority to make authentic deeds regarding certain legal actions, for example regarding land rights or property rights over apartment units, and including credit agreement deeds are deeds made by a notary as evidence that certain legal actions have been carried out. The notary has carried out his duties and authorities in implementing the Credit Agreement and binding Mortgage Rights at BRI KCP Maguwoharjo, Sleman Regency in accordance with the applicable laws and regulations. Of course, Notaries in providing legal protection, justice and legal certainty for the parties, namely in the implementation of credit agreements and bonding of Mortgage Rights, there are often several problems faced by Notaries which then lead to debates between Banks, Debtors and Notaries.

\section{Research Methods}

This research uses a sociological juridical approach, because it is in accordance with the author's objective that this research is directly related to the community or leads to the reality of what is in the field. Sociological legal research, namely "legal research 
that obtains data from primary data", ${ }^{1}$ The researcher will start researching primary data first and then proceed to conduct secondary data research.

\section{Result and Discussion}

3.1. The Role of Notaries in Implementing Credit Agreements at BRI KCP Maguwoharjo, Sleman Regency

Researchers have conducted research and analyzed that the role of notaries in making credit agreement deeds is very important, in which notaries are required to be professional, one of which is bridging the interests of the Bank and debtors in making credit agreement deeds.

According to an interview with Notary Anita Kurniawati, SH.M.Kn², in implementing the credit agreement, as follows:

a. Check and receive the Credit Agreement creation file. Several conditions that must be completed by the Bank in making a Credit Agreement, namely:

1) Offering Letter (In the form of Bank provisions, an agreement between the Bank and the Debtor regarding the substance of the Credit Agreement, the Debtor's Identity and the Installation Value of the Mortgage)

2) Identity Card (IC) of the debtor (husband and wife) for married people and guarantor

3) Family Card of the debtor (husband and wife) for married people and guarantor

4) Marriage Certificate for those who are married

After these conditions have been completed, the Notary is obliged to carry out the authenticity of the data, the correctness of the data and the accuracy of the data, so that checking the correctness of the data and the accuracy of the data, such as checking the Identity Card Number (ICN) in the Ministry of Home Affairs system to see the truth of the data through the online system is not may be missed, if there are several conditions above that are not completed by the Debtor, the Notary will urge the Debtor through the Bank to be completed immediately.

$b$. The notary prepares the credit agreement deed

The file provided by the Bank is then checked in its entirety, if it is confirmed that the data is correct and the accuracy of the data is correct, the Notary is obliged to make a Credit Agreement Deed in accordance with the Offering Letter given by the Bank to the Notary.

According to an interview with the Head of the BRI KCP Maguwoharjo Sub-Branch, Mr. Sutardi ${ }^{3}$ namely that the implementation of this credit agreement is made with an

\footnotetext{
${ }^{1}$ Soemitro, Hanitijo Roni. (1990). Metodologi Penelitian Hukum dan Jurimetri. Jakarta: Ghalia Indonesia. p.89

2 Interview was conducted on January 15, 2020 with Mrs. Anita Kurniawati SH, M.Kn, Notary-PPAT Sleman Regency
} 
authentic deed by the Notary, carried out at the BRI Office with the Notary, BRI provides an Offering Letter (OL) to the Notary, to be processed the credit agreement deed with the substance as stated in the Offering Letter (OL), If the substance of the credit agreement when it is read out is not in accordance with OL, then I ask to be replaced and re-signed according to $\mathrm{OL}$.

From the results of the interview, the researcher can conclude that the notary has carried out his duties in accordance with what has been regulated in the legislation.

c. Ensure that the Credit Agreement process is in accordance with the laws and regulations, the Notary is responsible for:

1) Ensure that all Parties are present in the Credit Agreement including Banks, Debtors, and Witnesses

2) Ensure that the documents provided by the Bank match the parties present

3) Re-ensure the authenticity of Freehold Certificate (SHM) to the Debtor

4) Read out the contents of the Credit Agreement

5) Ensure that the parties know and understand the contents of the Credit Agreement

6) Ensuring the authenticity of the signatures and initials of the parties

7) In practice, the Notary has ensured the presence of the parties, for example in the credit agreement the First Party, namely the Bank and the Second, the Debtor, and witnesses have been mentioned.

The notary must keep the name of the debtor and the contents of the credit agreement confidential, this is in practice the notary can carry out in accordance with the applicable laws and regulations. If the Bank and the Debtor have problems or disputes among them, the Notary has the role of entering into the register book in order to be registered with the District Court. When researchers conduct research so far the Notary is always aware of several problems that have arisen between the Bank and the Debtor and the Notary has recorded it in the register book to be registered with the Court.

3.2. The Role of Notary in the Mortgage Bonding Process at BRI KCP Maguwoharjo, Sleman Regency

Based on an interview with a Notary Public Anita Kurniawati, SH, M.Kn, explained that the notary's duties in binding Mortgage Rights, namely: ${ }^{4}$

a. Carry out certificate checks at the local National Land Agency (BPN) Office or the local Land Office where the object is located. Notary-PPAT has the task of checking the certificate of land rights before being encumbered by the Mortgage Rights at the local National Land Agency (BPN) or at the local Land Office, whether the certificate is in dispute or not.

b. Checking the authenticity of supporting documents, namely: Identity Card (IC), Family Card (KK), Birth Certificate, Marriage Certificate, PBB, etc.

c. Preparing SKMHT or APHT to be signed by the parties, namely the Bank and the Customer (Debtor); The insurer must give direct power to the creditor to charge

\footnotetext{
${ }^{3}$ Interview was conducted on January 10, 2020 with Sutardi, Head of the BRI KCP Magawuharjo SubBranch, Sleman Regency

${ }^{4}$ Interview, Anita Kurniawati, Op.Cit.
} 
the insurance right. The mortgage provider or guarantee owner may not authorize or represent someone other than the creditor (Mortgage recipient) to charge the Mortgage Rights.

d. Registering APHT at the local National Land Agency (BPN) office no later than 7 (seven) working days from the date the APHT is signed; The registration is carried out by PPAT, not by the Mortgage holder even though he is an interested party. Take a Certificate of Mortgage (SHT) and Certificate of Land Rights that have been installed Mortgage Rights to the Bank (Creditor).

Based on an interview with a Notary Public Anita Kurniawati, SH, M.Kn, explained that the notary's duties in binding Mortgage Rights, namely: ${ }^{5}$

a. Carry out certificate checks at the local National Land Agency (BPN) Office or the local Land Office where the object is located.

b. Match all documents with data obtained from the Bank as Creditor. In making a deed, of course all documents must be appropriate and can be justified to avoid complicated problems that may come in the future due to inconsistencies in data.

c. The notary also has additional duties after the credit agreement between the creditor (Bank) and the debtor (customer) is completed, namely the Notary must go to the BPN office or the Land Office to carry out the Roya process for collateral used in the agreement because if this is not done by the Notary after the agreement completed, it can lead to a legal case in which the collateral is still bound by a guarantee with the previous agreement, causing the collateral to no longer be used as collateral for the Mortgage in the credit agreement in the future agreement, because in the records of the BPN office, the Guarantee Rights Guarantee still bound by the agreement with the previous agreement, so that here the Roya function is used to release the Mortgage Rights from the previous agreement which has ended so that the Guarantee Goods are not involved in an agreement process.

\subsection{Constraints faced by Notary Public when Implementing Credit Agreement}

Based on the research results, the researchers faced the obstacles faced by the Notary in implementing the credit agreement. According to Notary Anita Kurniawati, SH, M.Kn, it is as follows: ${ }^{6}$

a. The cost of making a notary credit agreement deed is felt heavy so that sometimes it takes time to reach an agreement between the debtor and the bank.

b. There are incomplete requirements from the debtor to complete the terms for implementing the credit agreement, such as an expired IC

\footnotetext{
${ }^{5}$ Ibid.

${ }^{6}$ lbid.
} 
c. At least the time given by the bank to the notary to prepare related documents with the implementation of the credit agreement

d. There is a notary's inaccuracy

The more the number of banks that face to ask the Notary to write down their wishes in one authentic deed, the greater the risk of errors made by the Notary in including the statements of the parties in the deed. The loss of a few words or mistakes in including information in the deed is a frequent occurrence so that in the credit agreement deed there are many renvoi or amendments, additions, replacements, substitutions or write-offs in the deed. If an error occurs in the substance of the agreement and the renvo $i$ is not carried out and results in confusion over the deed, the parties concerned can sue the Notary for the deed drawn up.

e. The bank officer negligence

In writing an incomplete Offering Letter (OL), due to the rush of time causing the substance of the OL itself to be wrong, causing the implementation of the credit agreement to be obstructed, the Bank must revise the OL. If OL has errors in its substance, it will affect the identity of the loan, the amount of the loan, the interest rate, the use of the loan, the name or form of goods, the place and location of the collateral.

f. The process of signing the credit agreement deed, which sometimes the First Party (Bank) is unable to attend the implementation of the credit agreement. How important is the credit agreement in the legal aspect, especially as a means of proof in generally. In general, the respective credit agreements for acknowledgment of debt. The difficulty is if the Bank Management is unable to do so, the implementation of the credit agreement or debt recognition itself will be delayed and it is certain that the disbursement of loan funds will be late.

\subsection{Constraints faced by Notaries During the Bonding Process of Mortgage Rights}

Based on an interview with the notary Anita Kurniawati, SH, M.Kn explained that: ${ }^{7}$

a. The certificate owner or mortgage provider was not present at the signing of the SKMHT or APHT. If the mortgage provider is unable to attend the signing of the SKMHT or APHT, the bonding of the Mortgage may not be carried out and postponed until the power of attorney and the power of attorney can attend to sign the SKMHT and APHT. This is because the power of attorney cannot be represented by anyone. To overcome this, the parties concerned should really agree on the time that has been determined together so that the installation process of the Mortgage can run smoothly and quickly.

\footnotetext{
${ }^{7}$ lbid.
} 
b. Object of Mortgage Rights is not in the work area of the Notary. The existence of land that will be used as Mortgage Rights can be located anywhere. Meanwhile, notaries only have a limited work area. So, if the object of the Mortgage that will be tied to the Mortgage is not in the working area of the bank partner Notary, then the certificate must be made SKMHT in advance by the Notary whose work area is in the location of the certificate. After the SKMHT is made, then the PPAT of the Bank partner can be paired with APHT.

c. In fact, there are still many cases that the receivables secured by uncertified ownership rights are only tied with SKMHT. Not all receivables can receive uncertified ownership rights as credit collateral, because if the uncertified property rights are not used as objects of mortgages, of course the creditors will lose their preferred rights. The absence of this creditor's preference right will create a risk if the creditor defaults ${ }^{8}$.

d. In binding Mortgage Rights to Banks and debtors, the granting of Mortgage Rights over land that is not yet certified is carried out in 2 (two) ways, namely through the Power of Attorney to Impose Mortgage Rights (SKMHT) and directly with the Deed of Assignment of Mortgage Rights (APHT). The use of SKMHT is done because land data is incomplete, both physical data and juridical data, while APHT is used because the statutory provisions allow it. The Bank's consideration of accepting uncertified land collateral due to statutory regulations and bank internal rules allows and other considerations are the character and business prospects of the debtor.

e. Bonding Mortgage that granting Mortgage on land that has not been certified is because the Bank does not pay attention to the juridical aspects if the debtor is in default, this is because it is often found that the land is still not certified. The community only holds Plank $\mathrm{D}$, letter $\mathrm{C}$ as proof that they have ownership of a plot of land, overcoming the obstacles faced by this Notary by explaining to the bank that Plank D or Letter C is not proof of land rights which ultimately cannot be encumbered by mortgage rights.

f. In the implementation of this collateral bonding, it must automatically have something to do with the BPN office. According to the UUHT, it is clearly stated that the granting of Mortgage Rights must be registered at the land office no later than 7 (seven) working days after the signing of the APHT. However, in reality in the field, after registering, sometimes there are still things that must be taken care of and it takes time, for example, the object of the Mortgage is the result of a sale and purchase and the original land certificate has not been reversed by the owner, so it must be processed to reverse the name first. Usually the process of transferring this name can take more than 7 (seven) working days.

\footnotetext{
${ }^{8}$ Chusna, Amalia., \& Hafidz, Jawade. (2019). The Role of the Notary in the Credit Agreement with Mortgage Guarantee (Case Study in the Bank Tabungan Negara (Persero) Tbk). JURNAL AKTA: Vol. 6, No. 4, 719-726. Retrieved from http://jurnal.unissula.ac.id/index.php/akta/article/view/7668
} 
Due to the large area of Sleman Regency, it can also be used as an excuse for the accumulation of work at the BPN office which hinders the smooth process of checking and registering Mortgage Rights. Indeed, the BPN office has to process many certificates. This is what delay the time of checking and registration of Mortgage Rights. Besides that, human resources are also inadequate.

\subsection{Solutions Made by Notaries in Facing Constraints During Credit Agreement Implementation}

Based on an interview with Notary Anita Kurniawati, SH, M.Kn, in facing obstacles during the implementation of the credit agreement, namely as follows: ${ }^{9}$

a. With the constraints on the cost of making a credit agreement deed by the notary public, the Bank, Debtor and Notary Public make a re-agreement regarding the costs to be incurred by the Debtor until all parties approve it.

b. If there are incomplete requirements from the debtor, for example, to complete the terms of implementing a credit agreement where the IC has expired, the Notary asks the Debtor through the Bank to be able to immediately take care of the IC to the District and sometimes if the Notary knows a partner in the District Office then the Notary asks for help from the partner to be able to assist in the process of issuing a Recording Certificate.

c. The little time given by the Bank, so that in making the credit agreement deed becomes an obstacle for the Notary, so that the solution provided by the Notary to the Bank is to be able to provide information to the Notary on when the credit agreement will be implemented or when the credit will be disbursed, the Bank long ago sent an Offering Letter (OL) to the Notary, so that the Notary still has time lag to prepare the credit agreement, other supporting documents at the time of the implementation of the credit agreement.

d. There is a notary's inaccuracy caused by the number of banks making several requests and changing policies or approvals with their debtors, so what the notary does in dealing with the bank's request in drafting deeds needs to pay more attention to focus on examining formal requirements, namely carefully paying attention to what is conveyed by the bank. either in the form of information regarding the agreement to be stated in an authentic deed or information regarding the identity of the parties, including ensuring the certainty of the parties' signatures as well as ensuring the date and place of the deed. Thus, what is conveyed by the parties can be properly written into the authentic deed to be made.

\footnotetext{
${ }^{9}$ Ibid.
} 
e. The negligence of bank officers in writing the incomplete Offering Letter (OL), due to rushed time causing the substance of the $\mathrm{OL}$ itself to be wrong, causing the implementation of the credit agreement to be obstructed, the Bank must revise the OL. If OL has errors in its substance, it will affect the identity of the loan, the amount of the loan, the interest rate, the use of the loan, the name or form of goods, the place and location of the collateral. Therefore, the Notary sometimes asks the Bank to check first before the $\mathrm{OL}$ is sent to the Notary, besides that the Notary always re-ensures to the Bank whether what is stated in OL has been confirmed to be correct and there is no revision.

f. The process of signing the credit agreement deed, which sometimes the First Party (Bank) is unable to attend the implementation of the credit agreement. The solution made by the Notary in dealing with this obstacle is to immediately instruct the Bank Management to appoint a temporary replacement so that the disbursement of loan funds is not too late.

Based on the researcher's analysis using the theory of legal certainty, the notary in carrying out his / her duties must be guided normatively by the rules of law related to all actions to be taken and then stated in a deed. Acting on the basis of the applicable legal rules will provide the party that the deed drawn up "before" or "by" the Notary is in accordance with the applicable legal rules, so that if a problem occurs, the Notary's deed can be used as a guide by the parties. ${ }^{10}$

As for legal certainty, according to Soerjono Soekanto: legal certainty requires the creation of general regulations or general principles in order to create a safe and peaceful atmosphere in society. ${ }^{11}$ Legal certainty can be achieved if certain situations:

a. There are legal rules that are clear (clear), consistent and easily accessible

b. The ruling (government) agencies apply these legal rules consistently and are also subject and obedient to them

c. The citizens in principle adapt their behavior to these rules

d. Independent and impartial judges (judiciary) apply these legal rules consistently whenever they resolve disputes

e. The judicial decisions are concretely implemented

\footnotetext{
${ }^{10}$ Habib Adjie (a). (2009). Hukum Notaris Indonesia Tafsir Tematik Terhadap UU No. 30 tahun 2004 Tentang Jabatan Notaris. Bandung: Refika Aditama, p. 37.

${ }^{11}$ Soerjono Soekanto (a). (1999). Beberapa Permasalahan Hukum dalam Kerangka Pembangunan di Indonesia (suatu tinjauan secara sosiologis), 4 Printing, Jakarta: Universitas Indonesia, p. 55.
} 
In the event that a Notary is a public official who has the authority to make an authentic deed that has perfect evidentiary power, the Notary deed must be made in the form prescribed by law, this is one of the characteristics of the Notary deed. If the Notary deed has met the existing provisions, the Notary deed provides legal certainty and protection to the parties regarding the agreement they have made. With his obedience, Notaries exercise part of the State's power in the field of civil law to serve the interests of the public who need evidence in the form of an authentic deed that has perfect legal certainty in case of problems. ${ }^{12}$

\subsection{Solutions Made by Notaries in Facing Constraints During the Bond Bonding Process}

According to an interview with the Notary Public Anita Kurniawati, SH, M.Kn, that there are ways to overcome the obstacles faced by Notaries in binding Mortgage Rights. But beforehand here I will explain how the procedures for binding Mortgage Rights are as follows: ${ }^{13}$

a. After the signing of the Deed of Granting of Mortgage Rights made by the PPAT is carried out by the parties, the Notary sends the relevant APHT and other documents required by the Land Office. The notary carries out the bonding of Mortgage Rights through several stages, including:

1) PPAT prepares the deed in advance.

2) Then after checking is declared appropriate, the next implementation is to determine the time agreed upon by both parties, namely the Giver of Mortgage and the recipient of the Mortgage to appear before the Notary.

b. After it has been agreed that all matters related to the imposition of Mortgage Rights, the deed will be read out by the Notary and its contents explained.

c. If all the contents of the deed have been understood by the parties, then it will be followed by the signing by the mortgage provider, the Mortgage, two witnesses, and the Notary himself.

d. The provisions in our land law state that the Deed of Encumbrance (APHT) after being signed, within seven working days after that registration must be made at the Office of the National Land Agency (BPN).

e. Registration of Mortgage Rights is carried out by the Land Office by making a land title and recording it in the land book of land rights which are the object of the Mortgage Rights and copying the records on the certificate of land title concerned.

\footnotetext{
12 Op.Cit. Habib Adjie p. 42.

${ }^{13}$ Interview, Anita Kurniawati, Op.Cit.
} 
f. The date of the land book of the Mortgage Rights is the seventh day after receipt of complete documents required for registration and if the seventh day falls on a holiday, the land book concerned shall be given a date of the next working day.

g. Mortgage certificate and land title certificate are then submitted to the creditor (bank) as the holder of the Mortgage Rights for safekeeping.

Power of Attorney to Charge Mortgage Rights or abbreviated as SKMHT is the power given by the guarantor of the Mortgage as the power of attorney to the special power recipient to charge an object with the Mortgage Rights The SKMHT giver here is the collateral owner, possibly as a debtor at the same time but may not be a debtor but only as the collateral owner. While the SKMHT recipient is confirmed to be a creditor, it cannot be an individual who is not a creditor. In implementation in the field, not a few creditors use the SKMHT for various reasons.

Activities related to land issues are never separated from their affairs with the land office. In the implementation of this collateral agreement, automatically there must be a connection with the BPN office. According to the UUHT, it is clearly stated that the granting of Mortgage Rights must be registered with the land office no later than 7 (seven) working days after the signing of the APHT. However, in reality in the field, after registering, sometimes there are still things that must be taken care of and it takes time, for example, the object of the Mortgage is the result of a sale and purchase and the original land certificate has not been reversed by the owner, so it must be processed to reverse the name first. Usually the process of transferring this name can take more than 7 (seven) working days.

Due to the large area of Sleman Regency, it can also be used as an excuse for the accumulation of work at the BPN office which hinders the smooth process of checking and registering Mortgage Rights. Indeed, the BPN office has to process many certificates. This is what delay the time of checking and registration of Mortgage Rights. Besides that, human resources are also inadequate.

So that's why sometimes the old notary in giving SHT to creditors because constraints from the BPN office often occur in the field, this is usually related to delayed processing time in processing from registration to issuance of the Certificate of Mortgage. The reason given by the BPN regarding the delay was due to the large number of deeds or documents that BPN staff had to work on as well as remembering the limited human resources and infrastructure.

In the event that the collateral bonding to the collateral object which is still in the process of being converted to a mortgage title does not exist or does not exist, the Land Office may not be able to carry out the process of copying and recording the mortgage land book, therefore a certificate will be made immediately by a notary 
public. Based on the theory of justice according to Aristotle is that the notary's step when facing obstacles in binding the Mortgage lies between giving too much and little which can be interpreted as giving something to everyone according to what is their right. Because Justice comes from the word "FAIR" which means impartial, impartial (to the right), hold on to the truth (rightly), and not arbitrarily. ${ }^{14}$ In essence, justice is an attitude to treat someone according to their rights, so that the Notary Public in giving his rights to the Bank and Debtor must be appropriate. And what is the right of every person is to be recognized and treated in accordance with his dignity, equal rank, the same rights and obligations, without discrimination. ${ }^{15}$

\section{Closing}

Solution which made by the Notary in facing obstacles when making a Credit Agreement and binding Mortgage Rights, among others, is to provide solutions regarding the presence of inhibiting factors from the Bank. Therefore, the solution used by the notary is to provide understanding, direction and warning to the bank not only to think about credit sales targets quickly, while they are not ready with the required documents. In other words, they must also have the support and awareness to work strongly and must be able to work more professionally, overcoming the obstacles faced by the Notary in binding Mortgage Rights from the BPN office related to delayed processing time from registration to issuance of the Mortgage Certificate. The reason given by BPN regarding the delay was due to the large number of deeds or documents that BPN staff had to work with and given the limited human resources and infrastructure. Thus, the solution used is to use an accelerated process from the Notary, which costs more for the smooth running of all the bonding mortgage processes.

\section{References}

Journals:

Chusna, Amalia., \& Hafidz, Jawade. (2019). The Role of the Notary in the Credit Agreement with Mortgage Guarantee (Case Study in the Bank Tabungan Negara (Persero) Tbk). JURNAL AKTA: Vol. 6, No. 4, 719-726. Retrieved from http://jurnal.unissula.ac.id/index.php/akta/article/view/7668

Rizka Maulinda, Dahlan, M. Nur Rasyid, Perlindungan Hukum bagi Pekerja Kontrak Waktu Tertentu dalam Perjanjian Kerja pada PT. IU Kanun, Jurnal IImu Hukum, Vol. 18, No. 3, (Desember, 2016)

\footnotetext{
${ }^{14}$ Rizka Maulinda, Dahlan, M. Nur Rasyid, Perlindungan Hukum bagi Pekerja Kontrak Waktu Tertentu dalam Perjanjian Kerja pada PT. IU Kanun, Jurnal IImu Hukum, Vol. 18, No. 3, (Desember, 2016), p. 337351

${ }^{15}$ Aristotle, in Aristotle's Theory or Concept of Justice, http://www.siswamaster.com/2016/01/teorikeadilan-menurut-aristoteles-dan-contoh.html, accessed on 29 November 2018.
} 
Books:

[1] Soemitro, Hanitijo Roni .1990. Metodologi Penelitian Hukum dan Jurimetri.Jakarta:Ghalia Indonesia

[2] Habib Adjie (a). (2009). Hukum Notaris Indonesia Tafsir Tematik Terhadap UU No. 30 tahun 2004 Tentang Jabatan Notaris. Bandung: Refika Aditama

[3] Soerjono Soekanto (a). (1999). Beberapa Permasalahan Hukum dalam Kerangka Pembangunan di Indonesia (suatu tinjauan secara sosiologis), 4 Printing, Jakarta, Universitas Indonesia

Internet:

Aristotle, in Aristotle's Theory or Concept of Justice, http://www.siswamaster.com/2016/01/teori-keadilan-menurut-aristoteles-dancontoh.html, accessed on 29 November 2018.

Interview:

[1] Interview was conducted on January 15, 2020 with Mrs. Anita Kurniawati SH, M.Kn, Notary-PPAT Sleman Regency

[2] Interview was conducted on January 10, 2020 with Sutardi, Head of the BRI KCP Magawuharjo Sub-Branch, Sleman Regency 